\title{
Review
}

\section{ICE, neuronal apoptosis and neurodegeneration}

\author{
Robert M. Friedlander ${ }^{1}$ and Junying Yuan $^{2,3}$ \\ ${ }^{1}$ Neurosurgical Service, Department of Surgery, Massachusetts General \\ Hospital, Harvard Medical School, Boston, Massachusetts 02114 USA \\ 2 Department of Cell Biology, Harvard Medical School, 240 Longwood Avenue, \\ Boston, Massachusetts 02115, USA \\ 3 corresponding author: tel: 617 432-4170; fax: 617 432-4177; \\ email: jyuan@hms.harvard.edu
}

Received 20.3.98; revised 18.6.98; accepted 23.6.98 Edited by G. Melino

\begin{abstract}
Significant progress has recently occurred in the understanding of the molecular mechanisms mediating vertebrate programmed cell death, or apoptosis. New advances in this field have stemmed from the identification of ICE (caspase-1) as the founding member of the mammalian caspase cell death family. Apoptotic cell death plays an important role in neuronal cell death. Both in vitro and in vivo evidence implicates ICE as an important factor in neuronal apoptosis, especially under pathological conditions. In addition, other caspases, such as caspase-3, have also been shown to be activated and may play a role in pathological neuronal loss. Understanding the basic mechanisms mediating cell death in neurodegenerative disease may lead to the development of novel approaches for the treatment of diseases featuring apoptosis.
\end{abstract}

Keywords: apoptosis; ICE; caspase; pathological cell death

Abbreviations: ICE, interleukin - $1 \beta$ converting enzyme; pro-IL-1 $\beta$, pro-interleukin-1 $\beta$; LPS, lipopolysaccharide; ALS, amyotrophic lateral sclerosis; SOD, superoxide dismutase; HT, Hashimoto's thyroiditis; IFN- $\gamma$, interferon- $\gamma$; NO, nitric oxide; NMMA, Nmonomethyl-L-arginine; PARP, poly (ADP-ribose) polymerase; NMDA, N-methyl-D-aspartate; HD, Huntington's disease; DRPLA, Dentatorubropallydoluysian atrophy; MJD, Machado-Joseph disease; APP, amyloid protein precursor; PS, prenesilin

\section{Introduction}

Programmed cell death or apoptosis, a process by which organisms eliminate unwanted cells, is executed through the activation of a tightly regulated program (Wyllie et al, 1980; Yuan and Horvitz, 1990; Yuan et al, 1993). Amounting evidence exists linking aberrant apoptosis with different disease processes. Excessive apoptosis plays an important role in neurodegenerative diseases as well as following cerebral ischemia and head trauma (Friedlander et al, 1997b; Hara et al, 1997b; Kostic et al, 1997; Li et al, 1995a,b; Verheij et al, 1996; Yakovlev et al, 1997).
Neurodegenerative illnesses are a heterogeneous group of diseases sharing the common feature of progressive cell death within the nervous system. Neuronal loss, a hallmark of neurodegenerative diseases, is thought to be mediated at least in part following the activation of apoptotic pathways (Friedlander et al, 1997a; Hara et al, 1997b; Kostic et al, 1997; Portera-Cailliau et al, 1995; Thomas et al, 1995; Vito et al, 1996; Wolozin et al, 1996).

In order to understand the role of apoptotic cell death in neurodegenerative diseases, we must first define the mechanistic pathways mediating apoptosis. It has been only recently however, that the genetic and biochemical mechanisms of apoptosis have began to be elucidated. A genetic pathway of programmed cell death was first identified in the nematode Caenorhabditis elegans. In this worm, the products of the ced- 3 and ced- 4 genes are required for cellular suicide, whereas the ced-9 gene product prevents apoptosis (Hengartner et al, 1992; Yuan and Horvitz, 1990). Interleukin-1 $\beta$ converting enzyme (ICE), a cysteine protease responsible for the activation of pro-interleukin-1 $\beta$ (pro-IL-1 $\beta$ ), is a mammalian homolog of CED-3 (Miura et al, 1993; Yuan et al, 1993). An enlarging family of vertebrate cell death genes have been identified sharing structural and functional homology with CED-3 and ICE. These cell death effectors, also known as caspases, are cysteine proteases with a conserved QACXG sequence in the active site. To date, at least ten additional members of the ICE/CED-3 family have been identified: caspase-2 (ICH-1/NEDD2), caspase-3 (CPP32/ Yama/Apopain), caspase-4 (TX/ICH-2/ICE $\left.\mathrm{Cel}_{\text {rel }} \mathrm{l}\right)$, caspase-5 (ICE $\mathrm{Iel}_{\mathrm{III}}$ ), caspase-6 (MCH2), caspase-7 (MCH3/CMH-1/ ICE-LAP3), caspase-8 (MCH5/FLICE/MACH), caspase-9 (MCH6-ICE-LAP6), caspase-10 (MCH4), and caspase-11 (ICH-3) (Boldin et al, 1996; Duan et al, 1996a,b; Faucheu et al, 1995; Fernandes-Alnemri et al, 1994, 1995a,b; Kamens et al, 1995; Kumar et al, 1994; Lippke et al, 1996; Munday et al, 1995; Munzio et al, 1996; Nicholson et al, 1995; Tewari et al, 1995; Wang et al, 1995, 1996). Caspases can be divided into three subfamilies based upon their sequence homologies: (1) ICE subfamily which consists of caspase-1, 4, 5 and 11 ; (2) caspase-2 subfamily which consists of caspase-2 and 9 ; (3) caspase-3 subfamily which consists of caspase-3, 6, 7, 8 and 10. Recently, a mammalian homolog of ced-4 has been identified (Zou et al, 1997). The Bcl-2 family of proteins are homologs of the $C$. elegans ced-9 protein (Hengartner and Horvitz, 1994). These discoveries identified an evolutionary conserved cell death pathway, and laid the background for the study of the basic mechanisms of mammalian apoptosis. Understanding the mechanistic basis of apoptosis will provide tools to study their relation to the pathogenesis of neurodegeneration as well as to other diseases featuring apoptosis. 
Evaluating the impact of apoptosis and the possible roles of caspases in neurodegenerative diseases has taken several different approaches. Study of human brain specimens of patients affected with a variety of neurological diseases has yielded evidence of apoptosis (PorteraCailliau et al, 1995; Thomas et al, 1995). These important findings highlight the necessity to examine the impact of programmed cell death pathway activation in the pathogenesis and progression of neurodegenerative diseases. In vitro studies have identified a number of gene products involved in neurodegenerative diseases which are substrates of caspases, hence suggesting a possible role for caspases in neurodegeneration (Goldberg et al, 1996; Miyashita et al, 1997). The use of transgenic models, both of mice expressing genes leading to neurodegenerative diseases as well as of mice expressing inhibitors of apoptosis, have greatly increased our power to study the possible role of caspases in the pathogenesis of neurodegenerative diseases in vivo (Friedlander et al, 1997a; Gurney et al, 1994; Kostic et al, 1997). We will review evidence implicating caspases, in particular ICE, with neuronal apoptosis in vitro as well as with neurodegenerative diseases.

\section{ICE in apoptosis}

ICE was the founding member of the mammalian caspase family (Miura et al, 1993; Yuan et al, 1993). Its structural homology with the $C$. elegans cell death ced-3 product raised the possibility of it playing a role in mammalian cell death. Later findings in ICE knockout mice revealed that deletion of the Ice gene alone did not result in developmental cell death defects. These findings led many people to conclude that ICE does not play a role in cell death (Kuida et al, 1995; Li et al, 1995c). We will critically examine this hypothesis by evaluating all the published evidence to date.

Ice knockout mice develop normally: their brains are normal in size and their lymphocytes undergo apoptosis appropriately in response to most stimuli (Kuida et al, 1995; Li et al, 1995c). Ice-/- thymocytes have a partial defect in response to Fas stimulation (Kuida et al, 1995); since human thymocytes do not undergo apoptosis in response to Fas and Ice-I- mice do not develop autoimmune diseases, this defect may not be significant in terms of immune system function. We did find, however, that Ice-/ - dorsal root ganglion neurons are partially resistant to apoptosis induced by trophic factor deprivation, suggesting that ICE plays a role in regulating sensory neuron cell death (Friedlander et al, 1997b). These studies ruled out a major non-redundant role of ICE in developmental cell death, and suggests that ICE may play a role regulating sensory neuron cell death. Since $/ c e-/-$ knockout mice are only deficient in the expression of $/ c e$, it is still possible that the role of ICE is redundant, and only when we eliminate other caspase function as well, will we then see a major phenotype. This will be hardly surprising since most cells express more than one caspase.

Although the role of ICE in development is either redundant or minor, its role in pathological cell death appears to be significant and non-redundant. Evidence supporting this conclusion came in part from using a transgenic mouse that we generated expressing a dominant negative ICE inhibitor under the control of the neuronal specific enolase promoter (NSE-M17Z) (Friedlander et al, 1997b). The mutant ICE-lacZ construct has the active-site cysteine substituted for a glycine. Microinjection of the mutant lce construct into chicken dorsal root ganglion neurons inhibited neuronal cell death induced by trophic factor deprivation, suggesting that mutant ICE can act as an inhibitor of neuronal cell death (Friedlander et al, 1997b; Li et al, 1996). NSE-M17Z mice are developmentally and behaviorally normal. This result was expected if the mutant ICE inhibits the ICE pathway since the Ice knockout mouse is similarly normal. To evaluate whether mutant ICE was indeed a dominant negative ICE inhibitor, we examined secretion of mature IL-1 $\beta$ upon stimulation of bacterial endotoxin lipopolysaccharide (LPS) in wild-type and NSEM17Z transgenic mouse. High dose of LPS is a strong inducer of pro-inflammatory cytokine release including mature IL-1 $\beta$ (Kuida et al, 1995; Li et al, 1995). Intraperitoneal injection of LPS, induced an elevation in the levels of mature IL-1 $\beta$ in the brain. In the NSE-M17Z mice, however, the increase of mature IL-1 $\beta$ levels was significantly attenuated (Friedlander et al, 1997b). These results indicate that mutant ICE is a specific inhibitor of the ICE pathway, since ICE is required for pro-IL-1 $\beta$ processing in mice (Kuida et al, 1995; Li et al, 1995c). To evaluate the role of ICE in pathologic cell death, we will describe evidence linking ICE mediated apoptotic cell death following cerebral ischemia and in amyotrophic lateral sclerosis (ALS) (Friedlander et al, 1997a,b).

\section{ICE apoptotic pathways mediate cerebral ischemia-induced injury}

Several lines of evidence suggest that apoptosis is an important cell death pathway mediating cell death following cerebral ischemia. In animal stroke models, markers of apoptosis such as cytoplasmic and nuclear condensation as well as DNA fragmentation (TUNEL staining and DNA laddering) appear in neurons particularly in the infarct penumbra (Charriaut-Marlangue et al, 1996; Li et al, 1995a,b; MacManus et al, 1994). To examine if caspases play a role mediating cerebral ischemia-induced apoptosis, we first evaluated the NSE-M17Z transgenic mouse in a model of permanent focal cerebral ischemia. We found that the mutant Ice transgenic mice were resistant to ischemic injury when compared to the wild-type: infarct sizes were $48 \%$ smaller and behavior scores were more than $50 \%$ improved in the transgenic group compared with their wild-type littermate controls (Friedlander et al, 1997b). This was a very exciting finding since it suggests that modulation of apoptotic pathways by caspase inhibition may be used as a therapeutic tool for the treatment of cerebral ischemia. Similar protection was demonstrated in the mutant /ce transgenic mice following an ischemia reperfusion paradigm (Hara et al, 1997a). In addition, intracerebroventricular administration of synthetic peptide inhibitors of the ICE family also demonstrated a reduction of cerebral ischemia-mediated infarct size as well as improved behavioral scores (Hara et al, 1997b). To evaluate 
whether ICE is activated during ischemia, we measured mature IL-1 $\beta$ levels in ischemic brain tissue. A significant elevation of mature IL-1 $\beta$ production was detected, indicating activation of ICE following ischemic injury (Hara et al, 1997b). The elevation of mature IL- $1 \beta$ following cerebral ischemia was attenuated in the NSE-M17Z mice (Hara et al, 1997a). The critical role of ICE in mediating ischemic brain injury was further supported by the work on the ICE knockout mice. Schielke et al (1998) showed that the cerebral edema and brain injury induced by focal cerebral ischemia were significantly reduced in the ICE knockout mice. These experiments suggest that activation of the ICE pathway is critical for apoptosis in the adult brain induced by ischemic injury and that inhibition of ICE may be a good therapeutic strategy for the treatment of cerebral ischemia in humans (Friedlander et al, 1997b; Hara et al, 1997a,b; Loddick et al, 1996).

What are the cell types that express ICE in brain? Bhat et al (1996) found that in the nonischemic hippocampal sections, the ICE immunoreactivity is associated with interneurons in the $\mathrm{CA} 1$ region. Four days after global forebrain ischemia, the increase in ICE immunoreactivity in layers of the hippocampus is most dramatic in microglia cells. This suggests that microglia may be the major source of mature IL-1 $\beta$ in ischemic brain and may directly contribute to neuronal cell death in a cell-nonautonomously manner (Figure 2).

\section{ICE in ALS}

To examine the role of ICE in neural degenerative diseases, we examined the possible effect of inhibiting ICE on the motor neuron degeneration in a mouse model of amyotrophic lateral sclerosis (ALS) (Gurney et al, 1994). ALS is an adult-onset motor neuron degeneratie disease that occurs both in sporadic and familial forms (de Belleroche et al, 1995). About $20 \%$ of familial ALS is associated with mutations in the

Normal condition: no caspase-11 expression

$$
\downarrow \text { Stress Signal }
$$

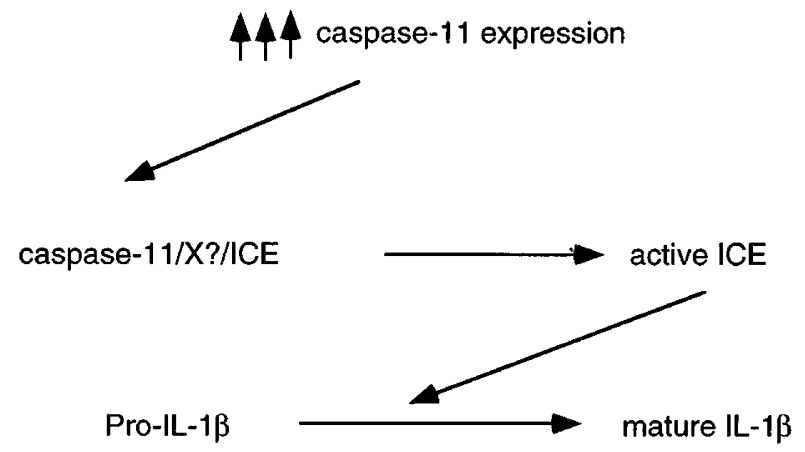

Figure 1 The activation of ICE pathway. The expression of caspase-11 is not detectable in normal healthy mice and is induced up to 40 -fold by certain pathological stimuli such as lipopolysaacharide. Elevated levels of caspase-11 interacts and activates pro-caspase-1. Active ICE processes pro-IL-1 $\beta$ to generate mature $\mathrm{IL}-1 \beta$ gene encoding the cytosolic copper-zinc superoxide dismutase gene (SOD) (Rosen et al, 1993). The major function of this enzyme is believed to be the detoxification through dismutation of the superoxide anion to form hydrogen peroxide, which in turn is detoxified by either glutathione peroxidase or catalase to form water (Brown, 1995). Although mutations in familial ALS do not always lead to a reduction of SOD function, down-regulation of SOD-1 activity in vitro by using antisense SOD-1 induces apoptosis in a neuronal cell line (Rothstein et al, 1994). Regulation of reactive oxygen species has been shown to play important roles in mediating cell death. A transgenic mouse model of familial ALS has been generated expressing a mutant allele of human SOD-1 (Gurney et al, 1994). Expression of high levels of this human SOD-1 mutant protein containing a substitution of glycine to alanine at position 93-a change that has little effect on enzyme activity-caused motor neuron degeneration and paralysis similar to human ALS. In order to evaluate if the ICE family may mediate cell death in the ALS model, we generated double transgenic mice by crossing the mutant SOD-1 with the mutant Ice transgenic mice. Mutant SOD-1 and mutant SOD-1/mutant Ice mice developed the ALS-like disease at approximately the same time. However, the double transgenic mice survived more than twice as long following the onset of the disease when compared to the single transgenic mice (Friedlander et al, 1997a). This result demonstrates that the ICE cell death pathway plays a significant role in the progression of ALS in these transgenic mice. The mechanism by which ICE mediates the progression of ALS is not yet clear. It is interesting to note that elevated mature IL-1 $\beta$ was detected in SOD transgenic mice after the onset of symptoms (unpublished results), suggesting that ICE is activated in this mouse model of ALS. It is posssible that IL$1 \beta$ played an active role in promoting neuronal cell death initiated by SOD mutations. Interestingly, shortly following our report demonstrating that mutant ICE inhibited the progression of ALS in this mouse model, another report described that $\mathrm{Bcl}-2$ over-expression delayed the onset of symptoms but not disease progression in this ALS mouse model (Kostic et al, 1997). Thus, it appears that expression of Bcl-2 delays neuronal cell death initiated by mutant SOD but such block by $\mathrm{Bcl}-2$ is eventually overcome by the mutant SOD, whereas expression of mutant ICE does not affect the initiation of neuronal cell death but delays the disease progression perhaps by delaying the secondary neuronal loss mediated by ICE and by cytokines. Both of these reports have important therapeutic implications for ALS. Specific activation of Bcl-2 in motor neurons of patients with inherited mutant SOD alleles may delay the onset of motor neuron degeneration, whereas treatment with ICE inhibitors may delay the disease progression following its onset in familial as well as sporadic ALS patients.

What is the mechanism by which mutant ICE inhibits neuronal cell death? Since mutant Ice transgenic mice have reduced secretion of mature $\mathrm{IL}-1 \beta$ both after lipopolysaccharide administration and following ischemia, it appears that the mutant ICE is an effective inhibitor of the ICE pathway (Friedlander et al, 1997b; Hara et al, 1997a). We may envision intrinsic and extrinsic cellular mechanisms by which inhibition of the ICE pathway may result in inhibition of 
neuronal cell death. Since we have shown that expression of a microinjected mutant lce expression construct into chicken DRG neurons, and mouse cililary or DRG neurons, effectively inhibited neuronal cell death induced by trophic factor deprivation (Friedlander et al, 1997b; Li et al, 1996). These findings suggest that mutant ICE inhibits the intrinsic cell death pathway within neurons. However, we must point out that it is not clear whether mutant ICE is inhibiting the ICE pathway in the neurons. First, microinjection usually results in high levels of expression of the injected construct and when a mutant protein is expressed at high levels, it may interact with other proteins with which it may not interact when at low levels. Second, it has not been definitively demonstrated whether DRG neurons express ICE. DRG neurons from mutant Ice transgenic mice and Ice knockout mice are resistant to trophic factor deprivation, suggesting that the ICE pathway is important for DRG neuronal cell death induced by trophic factor deprivation since the mutant lce transgenic mice expressing low levels of the mutant ICE and the Ice knockout mice affects specifically the ICE pathway (Friedlander et al, 1997b). We cannot rule out, however, that the effect of the mutant ICE in the transgenic mice and the lce knockout mutation affects the survival of DRG neurons in a cell extrinsic manner since the neuronal enolase promoter also directs expression in oligodendrocytes and astrocytes (Burne et al, 1996) and the Ice knockout mutation certainly affects all of the cells in the mutant mice. ICE is an important regulator of IL-1 $\beta, \mathrm{IL}-1 \alpha$ and interferon- $\gamma(\mathrm{IFN}-\gamma)$. IL-1 and IFN- $\gamma$ are proinflammatory cytokines that elicit multiple cellular responses; both IL-1 $\beta$ and IFN- $\gamma$ can induce cell death under certain conditions (Friedlander et al, 1996; Hu et al, 1997). We have demonstrated that mature $\mathrm{IL}-1 \beta$ may mediate cell death perhaps in autocrine or paracrine fashion (Friedlander et al, 1996). Thus, it is yet to be shown whether mutant ICE inhibits neuronal cell death in a cell-autonomous or a cellnon-autonomous fashion.

\section{Activation of ICE}

Since the ICE pathway plays a pivotal role in mediating apoptosis under certain pathological conditions, it is important for us to understand the mechanism of ICE activation. Although recombinant pro-ICE has been shown to autoprocess itself during purification process (Ramage et al, 1995), this does not seem to occur in vivo (Wang et al, 1998). Activation of ICE in vivo requires another caspase, caspase11 (Wang et al, 1998). Caspase-11 is a member of ICE subfamily of caspases and its amino acid sequence shares $54 \%$ of identity with ICE (Wang et al, 1996). While expression of Ice is constitutive in many tissues and cell types, the expression of casp-11 in healthy mice cannot be detected on Northern and Western blots. Upon stimulation of lipopolysaccharide (LPS), a bacteria endotoxin, the expression of casp11 can be induced up to 40 -fold while Ice expression is not altered in most tissues. These evidence support a regulatory role of caspase-11 in mediating ICE activation. Indeed, in a transfection system, expression of casp-11 did not directly process pro-IL-1 $\beta$ but promoted the ability of ICE to process pro-IL-1 $\beta$ (Wang et al, 1996).
Definitive evidence for caspase-11 mediated ICE activation came from analysis of casp-11 mutant mice (Wang et al, 1998). The phenotypes of casp-11-/- are very similar to that of Ice-/- mice (Kuida et al, 1995; Li et al, 1995c). Like Ice-/- mice, casp-11-/- mice are also resistant to the lethality induced by LPS which can be attributed to the inability in producing mature IL-1 $\beta$ and IL-1 $\alpha$ (Wang et al, 1998). Production of mature IL- $1 \beta$ is a specific marker of ICE activation since ICE is the only enzyme that can process pro-IL-1 $\beta$, this suggests that caspase-11 is essential for ICE activation (Kuida et al, 1995; Li et al, 1995c). Indeed, Wang et al (1998) showed that in casp-11-/- embryonic fibroblast cells, the activation of ICE cannot occur.

How does caspase-11 activate pro-ICE? Wang et al showed that pro-caspase-11 can physically interact with pro-ICE (Wang et al, 1998). A simple pathway of ICE activation was proposed: under pathological conditions, the transcription and translation of caspase-11 is stimulated and newly synthesized caspase-11 interacts with pro-ICE to mediate its activation (Figure 1). The precise mechanism of pro-caspase-11 and pro-ICE interaction, however, is not yet clear: additional players may be present since direct caspase-11 and pro-ICE heterodimers cannot be detected in vitro (Wang et al, 1998).

\section{The downstream effectors of the ICE pathway: IL-1 $\beta$ and IFN- $\gamma$}

So far, ICE has been shown to regulate the secretion of mature IL- $1 \beta$ by processing pro-IL- $1 \beta$ directly and IFN- $\gamma$ indirectly through regulation of IL-18 or interferon- $\gamma$ inducing factor (IGIF) (Akita et al, 1997; Thornberry et al, 1992). Both $\mathrm{IL}-1 \beta$ and IFN- $\gamma$ are multifunctional cytokines that affect multiple cell types and elicit powerful cellular and systemic responses. Responses to $\mathrm{IL}-1 \beta$ appear to be largely dependent on cellular context. In some cells, IL-1 $\beta$ is a growth factor and $\mathrm{IL}-1 \beta$ stimulation is associated with phosphorylation of p42/p44 MAP kinase (e.g. mesangial cells), or activation of NF- $\kappa \mathrm{B}$ (Huwiler and Pfeilschifter, 1994; Osborn et al, 1989). On the other hand, the evidence is accumulating that IL-1 $\beta$ may contribute actively to cellular destruction by apoptosis (Friedlander et al, 1996; Relton and

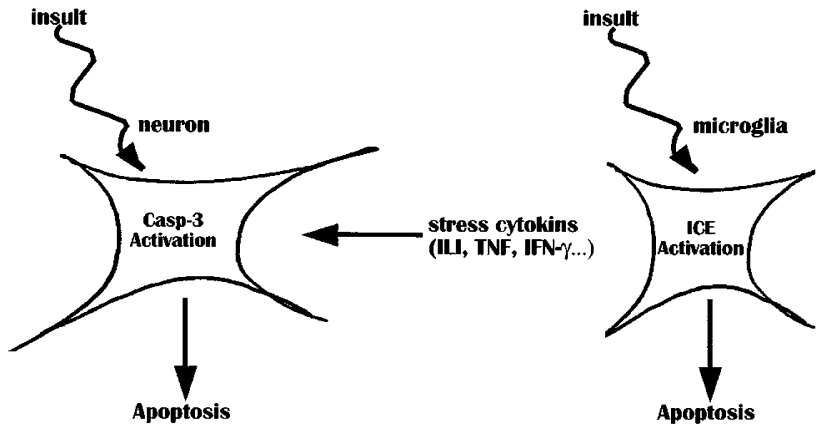

Figure 2 A model for possible interplays of caspases under certain pathological conditions. A pathological insult may lead to activation of caspase-3 directly in neurons in the center of damage. At the same time, such insult may activate the ICE pathway in cells such as microglia which leads to the release of stress cytokines (IL-1 $\beta$ and interferon- $\gamma$ ) in the marginal zones and lead to secondary neuronal cell death 
Rothwell, 1992; Troy et al, 1996). Hashimoto's thyroiditis (HT) is an autoimmune disorder in which destructive processes with typical features of apoptosis lead to thyrocyte loss. This self-destructive process appears to be initiated directly by elevated IL-1 $\beta$ due to inflammation in patients, which in turn induced expression of large amounts of Fas receptor on the surface of thyroid follicular cells (Giordano et al, 1997). This elegant study illustrated an example in which a proinflammatory cytokine such as IL-1 $\beta$ may have a direct effect on apoptosis mediated by death domain-containing receptors. We predict that such inflammation induced apoptosis may be very common in diseases associated with inflammation and more examples may be discovered in future studies.

In recent years, increasing evidence suggests that cytokines may play an important role in mediating the pathogenesis of neurodegenerative diseases (Chao et al, 1995a). Microglial cells (the resident macrophages of the brain) could be a major source of IL-1 $\beta$ (Chao et al, 1995b; Lee et al, 1993), whereas infiltrated lymphocytes and natural killer cells appear to be the key producers of interferon- $\gamma$ (IFN- $\gamma)$ (Lewis and Wilson, 1990). We have found that elevated levels of mature IL-1 $\beta$ in animal models of ischemic injury (Hara et al, 1997a,b). Rothwell and colleagues have demonstrated that injection of IL-1Ra, a naturally existing IL-1 $\beta$ antagonist, reduced infarct volume following ischemic injury in rats (Relton and Rothwell, 1992). We have also demonstrated that inhibiting the IL-1 $\beta$ signaling pathway by either the IL-1Ra or neutralizing antibodies against $\mathrm{IL}-1 \beta$ and against IL-1 type 1 receptor reduced hypoxia induced apoptosis in HeLa cells (Friedlander et al, 1996). These results suggest that IL-1 $\beta$ plays a functional role mediating neuronal cell death in such conditions and inhibiting the signal transduction pathway of $\mathrm{IL}-1 \beta$ may be beneficial in the treatment of stroke.

IL-1 $\beta$ and IFN- $\gamma$ have also been shown to induce neuronal apoptosis in culture ( $\mathrm{Hu}$ et al, 1997). Treatment of mixed human neuronal/glial cell cultures with IFN- $\gamma$ plus IL-1 $\beta$ for 13 days induced a high output of nitric oxide (NO) accompanied by marked neuronal loss. Such cytokine mediated neuronal injury was associated with morphological features of apoptosis including DNA fragmentation. Treatment of neuronal cell cultures with the NO inhibitor Nmonomethyl-L-arginine (NMMA) significantly attenuated neuronal cell death, suggesting that IL-1 $\beta$ and IFN- $\gamma$ induce neuronal cell death through NO production. Since ICE is predominantly expressed in microglial cells in the central nervous system (R Rotello and J Yuan, unpublished result), inhibition of $\mathrm{IL}-1 \beta$ release in our mutant Ice transgenic mice is likely achieved through inhibition in microglial cells. It remains to be seen, however, whether such IL-1 $\beta$ and IFN- $\gamma$ induced neuronal cell death requires ICE or other caspases; if it does, then there may be a positive feedback loop between caspases and cytokines.

\section{Functional role of other caspases in neurodegenerative diseases}

Distinct from /ce knockout and the mutant /ce transgenic mice, caspase-3 knockout mice have severe defects in nervous system development resulting in premature death (Kuida et al, 1997). Apoptosis of thymocytes and cleavage of poly(ADPribose) polymerase (PARP) upon induction of apoptosis was normal in casp-3-/ - thymocytes. In contrast, the development of the nervous system was profoundly affected in casp$3-1-$ mice. Ectopic cell masses were found in the cerebral cortex, the hippocampus and the striatum. Such supernumerary cells caused secondary defects on brain structures and resulted in hydrocephalus with elevated intracranial pressures which may be the cause of their premature death. Although increase in cellularity and decrease in pyknotic cells in casp-3-1- mice comparing to that of wild-type are consistent with a defect of apoptosis in the developing nervous system, the phenotype of casp-3-/- mice is in striking contrast with the NSE-Bcl-2 transgenic mice. Although the NSE-Bcl-2 transgenic mice have a significant increase in neurons and glial cells in many areas of the brain, the Bcl-2 transgenic mice develop and behave normally (Matinou et al, 1994). Bcl-2 transgenic mice have significantly bigger brains, while casp-3-/- mice have smaller brains than their respective wild-types (Farlie et al, 1995; Martinou et al, 1994). These results suggest that while it is possible that absence of caspase-3 in casp-3-/ - mice blocked certain neuronal cell death, which remains to be tested in culture conditions, casp-3 mutation may have an effect on neuronal development distinct from blocking apoptosis.

Although caspases may have functions other than regulating apoptosis, it is likely that they play a very important role in regulating cell death in general. It is very common for a cell type to express multiple caspase family members, suggesting that some caspases may function in a redundant fashion. Although the exact identities of the caspases are not yet clear, combinations of certain caspases are likely to play a controlling role in developmental neuronal cell death. In a direct demonstration of usefulness of caspase inhibitors, Hara et al (1997b) showed that injection of peptide inhibitors intracerebroventricularly can reduce ischemic neuronal cell loss. Although the caspase targets of these peptide inhibitors are not yet clear, evidence of caspase- 3 activation has been observed in a number of neuronal injury models. Caspase- 3 is activated following a brain trauma (Yakovlev et al, 1997). Excitotoxicity, induced by excessive activation of glutamate receptors, has been postulated to underlie the neuronal cell death that occurs after ischemic or traumatic injury as well as a number of neurodegenerative diseases. Stimulation of $\mathrm{N}$-methyl-D-aspartate (NMDA) receptor of cerebellar granule neurons with low concentrations of glutamate induces activation of caspase- 3 and apoptosis which can be inhibited by the caspase-3 preferred inhibitor DEVD-CHO (Du et al, 1997). In vivo, direct injection of the nonselective caspase inhibitor z-VAD.fmk into the striatum can reduce toxicity by AMPA ( $\alpha$-amino-3-hydroxy-5-methyl4-isoxaole propionate) injection and to a lesser extent NMDA (Hara et al, 1997b). The most comprehensive study of caspase-3 activation in stroke so far was described in Namura et al (1998). Pro-caspase-3, but not activated caspase-3, is constitutively present in neurons throughout normal brain. Caspase-3 p20 immunoreactivity, detected by an antibody recognizing active caspase-3 only, became 
prominent in neurons after temporary $(2 \mathrm{~h})$ middle cerebral artery occlusion at the time of reperfusion. 12-24 $\mathrm{h}$ later, such caspase-3 immunoreactivity was found to be present in TUNEL positive cells. This work showed directly that ischemic brain injury induces activation of caspase-3 which then causes neuronal apoptosis. These experiments suggest that caspases may play a very important role in excitotoxocity and activation of caspase-3 in neurons may lead to apoptosis in a cell autonomous manner (Figure 2).

Recent evidence suggests that caspase mediated apoptotic cell death may also play a role mediating neurodegenerative diseases such as Huntington's diseases (HD) (Goldberg et al, 1996; Portera-Cailliau et al, 1995; Thomas et al, 1995). HD belongs to a group of eight disorders with remarkably similar features including Dentatorubropallydoluysian atrophy (DRPLA), MachadoJoseph disease (MJD), sinal and bulbar muscular atrophy and spinocerebellar ataxia types 1, 2, 6 and 7 (Wellington et al, 1997). The genetic defect in each of these diseases is expansion of a CAG trinucleotide in the coding region of their respective genes which are translated into a polyglutamine repeat. Growing evidence suggests that while the presence of a polyglutamine tract in a large protein may not make it toxic, the polyglutamine tracts on their own or when associated with a small truncated protein is toxic to the cells. Interestingly, both huntingtin and DRPLA proteins have been found to be substrates of caspase-3 in apoptosis, which raised the possibility that accidental cleavage of huntingtin and DRPLA may initiate a chain reaction of neuronal cell death in specific areas of brain (Goldberg et al, 1996; Miyashita et al, 1997). It is not yet clear, however, where the specificities arise in these diseases, since the expression of these genes are detected in many different tissue types while neuronal losses are very specifically targeted to certain areas of the brain. Identification of putative proteases responsible for cleavage of these disease gene products, possibly being certain caspases, is likely to be very informative in understanding the causative mechanisms in these diseases.

Alzheimer's disease is characterized by distinct neuropathological lesions, including intracellular neurofibrillary tangles, extracellular parenchymal and cerebrovascular amyloid deposits and selective neuronal cell death that particularly affects cholinergic neurons in the basal forebrain (Edelberg and Wei, 1996). The principal component of parenchymal amyloid plaque cores and cerebrovascular amyloid is the b/A4 amyloid protein, which is derived from cleavage of a large transmembrane protein, the b/A4 amyloid protein precursor (APP). One of the biochemical features of $A D$ is the increases in the levels of $\mathrm{IL}-1 \beta$ in the brain and spinal fluid (Griffin et al, 1989). Since ICE is essential for processing and secretion of mature IL-1 $\beta$, this suggests that the ICE pathway is activated in AD. IL-1 $\beta$ was found to increase the expression of APP mRNA as well as the processing and secretion of APP (Buxbaum et al, 1992; Goldgaber et al, 1989). A functional role of the ICE pathway in mediating neuronal loss of $A D$ remains to be examined in adequate transgenic models.
Most cases of early onset familial $A D$ are caused by mutations in the genes encoding presenilin-1 (PS-1) and presenilin-2 (PS-2) (Levy-Lehad et al, 1995; Roagev et al, 1995; Sherrington et al, 1995). It has been widely reported that PS-1 and PS-2 are found in extracts derived from a variety of cultured cells and from tissues are fragmented extensively by endoproteolytic processing events (Mattson et al, 1998). At early developmental stages the expected approximately $34-\mathrm{kDa} \mathrm{N}$-terminal proteolytic fragment of PS-1 and the approximately $38-\mathrm{kDa}$ fragment of PS-2 were detected. Later during differentiation an approximately $38-\mathrm{kDa}$ fragment for PS-1 and an approximately 42-kDa fragment for PS-2 were detected (Mattson et al, 1998). Although it is controversial whether this endoproteolysis is a physiologically normal intracellular event following presenilin expression, or an in vitro artifact, both PS's are indeed cleaved in apoptosis (Kim et al, 1997). Both PS-2 and PS-1 are in vitro substrates of caspases (Loestsher et al, 1997; Vito et al, 1997). Expression of ALG-3, a truncated PS2 cDNA, encodes an artificial $\mathrm{COOH}$-terminal PS2 segment as well as a physiological COOH-terminal PS2 polypeptide (PS2s) generated by both alternative transcription and proteolytic cleavage have dominant inhibition effect on apoptosis (Levy-Lehad et al, 1995; Vito et al, 1996). These results suggest a functional role of PS proteolytic cleavage on apoptosis although the in vivo significance of such cleavage in etiology of $A D$ remains to be examined.

\section{Conclusion}

We have reviewed evidence demonstrating a prominent role of apoptosis and caspase family in a variety of neurological diseases. The caspase cell death family has been implicated the pathogenesis of stroke, ALS, Huntington's and related diseases, and Alzheimer's disease (Friedlander et al, 1997a, b; Goldberg et al, 1996; Hara et al, 1997a,b; Kim et al, 1997; Loddick et al, 1996). Additional studies will likely demonstrate a role for caspases in other diseases. Activation of the ICE pathway is likely to be critically involved in stroke and maybe other inflammation related neuronal degenerative diseases as well. Other caspases may induce toxicity of certain disease gene products by proteolytic cleavage which releases toxic polypeptide.

Inhibitors of caspases may be therapeutically beneficial for the treatment of a number of diseases such as stroke, $A L S$, and perhaps $H D$ and $A D$. One of the potential side effect of inhibiting caspases is the development of tumors since inhibition of apoptosis has been shown to facilitate tumor development. In this regard, we would like to propose that specific inhibitors of ICE may be especially useful, since inhibition of the ICE pathway produced specific resistance to stroke and ALS with no associated developmental defect or tumor development in the NSE-M17Z mice at 2 years of life (Friedlander and Yuan, unpublished observation). Whether inhibition of other caspases may cause tumor development or have an adverse effect on normal development and homeostasis remains to be evaluated since caspase- 3 knockout mice die within a few weeks of birth. 
Targeting caspase inhibition for the treatment of neurodegenerative diseases can be approached by means of pharmacological and genetic strategies. Delivery of caspase inhibitors either directly into the central nervous system, or systematically for drugs which can cross the blood-brain barrier may be used as a therapeutic strategy. Alternatively, delivery of genetic inhibitors of apoptosis (i.e. Bcl-2 or mutant ICE), by gene therapy approaches may also be employed as a treatment strategy. It is apparent, that human trials using some of these strategies are likely to be part of the armamentarium for the treatment of humans affected by these untreatable, and frequently fatal group of diseases.

\section{Acknowledgements}

We would like to thank Dr Mike Moskowitz and the members of Yuan laboratory for stimulating discussions and Dr Mike Moskowitz and $\mathrm{Dr}$ Suyue Wang for critical reading of this manuscript. This work is supported in part by grants from National Institute of Neurological Diseases and Stroke (to JY), the Amyotrophic Lateral Sclerosis Association (to JY), Muscular Dystrophy Association (to RF) and Hereditary Disease Foundation (to RF).

\section{References}

Akita K, Ohtsuki T, Nakuda Y, Tanimoto T, Namba M, Okura T, Takakura-Yamamoto R, Torigoe K, Gu Y, Su MSS, Fujii M, Satoh-Itoh M, Yamamoto K, Kohno K, Ikeda $M$ and Kurimoto M (1997) Involvement of caspase-1 and caspase-3 in the production and processing of mature human interleukin 18 in monocytes and THP. 1 cells. J. Biol. Chem. 272: 26595-26603

Bhat RV, DiRocco R, Marcy VR, Flood DG, Zhu Y, Dobzanski P, Siman R, Scott R, Contreras PC, Miller M (1996) Increased expression of IL-1 beta converting enzyme in hippocampus after ischemia: selective localization in microglia $\mathrm{J}$. Neurosci. 16: $4146-4154$

Boldin MP, Goncharov TM, Goltsev YV and Wallach D (1996) Involvement of MACH, a novel MORT/FADD-interacting protease, in Fas/Apo-1 and TNF receptorinduced cell death. Cell 85: 803-815

Brown RHJ (1995) Amyotrophic lateral sclerosis: recent insights from genetics and transgenic mice. Cell 80: 687-692

Burne JF, Staple JK and Raff MC (1996) Glial cells are increased proportionally in transgenic optic nerves with increased numbers of axons. J. Neurosci. 16: 2064-2073

Buxbaum JD, Oishi M, Chen HI, Pinkas-Kramarski R, Jaffe EA, Gandy SE and Greengard P (1992) Cholinergic agonist and interleukin 1 regulate processing and secretion of the Alzheimer beta/A4 amyloid precursor protein. Proc. Natl. Acad. Sci. USA 89: 10075-10078

Chao CC, Hu S and Peterson PK (1995a) Glia, cytokines and neurotoxicity. Crit. Rev. Neurobiol. 9: 189-205

Chao CC, Hu S, Sheng WS and Peterson PK (1995b) Tumor necrosis factor-alpha production by human fetal microglial cells: regulation by other cytokines. Dev. Neurosci. 17: $97-105$

Charriaut-Marlangue C, Margaill I, Represa A, Popovici T, Plotkine T and Ben-Ari Y (1996) Apoptosis and necrosis after reversible focal ischemia: an in situ DNA fragmentation analysis. J. Cereb. Blood Flow and Metab. 16: 186-194

de Belleroche J, Orrell R and King A (1995) Familial amyotrophic lateral sclerosis/ motor neuron disease (FALS): a review of current developments. J. Med. Gen. 32: $841-847$

Du Y, Bales KR, Dodel RC, Hamilton-Byrd E, Horn JW, Czilli DL, Simmons LK, Ni B and Paul SM (1997) Activation of a caspase 3-related cysteine protease is required for glutamate-mediated apoptosis of cultured cerebellar granule neurons. Proc. Natl. Acad. Sci. USA 94: 11657-11662

Duan H, Chinnaiyan AM, Hudson PL, Wing JP, He WW and Dixit VM (1996a) ICELAP3, a novel mammalian homologue of the Caenorhabditis elegans cell death protein Ced-3 is activated during Fas- and tumor necrosis factor-induced apoptosis. J. Biol. Chem. 271: 1621-1625
Duan H, Orth K, Chinnayan AM, Poirier GG, Froelich CJ, HeWW and Dixit VM (1996b) ICE-LAP6, a novel member of the ICE/Ced-3 gene family, is activated by the cytotoxic T cell protease granzyme B. J. Biol. Chem. 13371-13376

Edelberg HK and Wei JY (1996) The biology of Alzheimer's disease. Mech. of ageing and Dev. 91: $95-114$

Farlie PG, Dringen R, Rees SM, Kannourakis G and BernardP (1995) bcl-2transgene expression can protect neurons against developmental and induced cell death. Proc. Natl. Acad. Sci. USA 92: 4397-4401

Faucheu C, Diu A, Edith Chan AW, Blanchet AM, Miossec C, Herve F, Dutilleul VC, Gu Y, Aldape RA, Lippke JA, Rocher C, Su MSS, Livingston DJ, Hercent T and Lalanne JL (1995) A novel human protease similar to the interleukin-1b converting enzyme induces apoptosis in transfected cells. EMBO J 14: 19141922

Fernandes-Alnemri T, Litwack G and Alnemri ES (1994) CPP32, a novel human apoptotic protein with homology to Caenorhabditis elegans cell death protein Ced-3 and mammalian interleukin-1 beta-converting enzyme. J. Biol. Chem. 269: $30761-30764$

Fernandes-Alnemri T, Litwack G and Alnemri ES (1995a) Mch2, a new member of the apoptotic Ced-3/lce cysteine protease gene family. Cancer Res. 55:2737-2742

Fernandes-Alnemri T, Takahashi A, Armstrong R, Krebs J, Fritz L, Tomaselli KJ, Wang L, Yu Z, Croce CM, Salveson G et al (1995b) Mch3, a novel human apoptotic cysteine protease highly related to CPP32. Cancer Res. 55: 60456052

Friedlander RM, Brown RH, Gagliardini V, Wang J and Yuan J (1997a) Inhibition of ICE slows symptoms of ALS. Nature 388: 31

Friedlander RM, Gagliardini V, Hara H, Fink KB, Li W, MacDonald G, Fishman MC, Greenberg AH, Moskowitz MA and Yuan J (1997b) Expression of a dominant negative mutant of ICE in transgenic mice prevents neuronal cell death induced by trophic factor withdrawal and ischemic brain injury. J. Exp. Med 185: 933-940

Friedlander RM, Gagliardini V, Rotello RJ and Yuan J (1996) Functional role of Interleukin 1b (IL-1b) in IL-1b-converting Enzyme-mediated apoptosis. J. Exp. Med. 184: 717-724

Giordano C, Stassi G, De Maria R, Todaro M, Richiusa P, Papoff G, Ruberti G, Bagnasco M, Testi R and Galluzco A (1997) Potential involvement of Fas and its ligand in the pathogenesis of Hashimoto's thyroiditis. Science 275: 960-963

Goldberg YP, Nicholson DW, Rasper DM, Kalchman MA, Koide HB, Graham RK Bromm M, Kazemi-Esfarjani P, Thornberry NA, Vaillancourt JP and Hayden MR (1996) Cleavage of huntingtin by apopain, a proapoptotic cysteine protease, is modulated by the polyglutamine tract. Nature Genetics 13: 442-449

Goldgaber D, Harris HW, Hla T, Maciag T, Donnelly RJ, Jacobsen JS, Vitek MP and Gajdusek DC (1989) Interleukin 1 regulates synthesis of amyloid beta-protein precursor mRNA in human endothelial cells. Proc. Natl. Acad. Sci. USA 86: $7606-7610$

Griffin WST, Stanley LC, Ling C, White L, MacLeod V, Perrot LJ, White CL and Araoz C (1989) Brain interleukin 1 and S-100 immunoreactivity are elevated in Down syndrome and Alzheimer's disease. Proc. Natl. Acad. Sci. USA 86 $7611-7615$

Gurney ME, Pu H, Chiu AY, DalCanto MC, Polchow CY, Alexander DD, Caliendo J, Hentati A, Kwon YW, Deng HX et al (1994) Motor neuron degeneration in mice that express a human $\mathrm{Cu}, \mathrm{Zn}$ superoxide dismutase mutation. Science 264: $1772-1775$

Hara H, Fink K, Endres M, Friedlander RM, Gagliardini V, Yuan J and Moskowitz MA (1997a) Attenuation of transient focal cerebral ishcemic injury in transgenic mice expressing a mutant ICE inhibitory protein. J. Cereb. Blood Flow Metab. 17: $370-375$

Hara H, Friedlander RM, Gagliardini V, Ayata C, Fink K, Huang Z, Shimizu-Sasamata M, Yuan Y and Moskowitz MA (1997b) Inhibition of ICE family proteases reduces ischemic and excitotoxic neuronal damage. Proc. Nat. Acad. Sci. USA 94: 2007-2012

Hengartner MO, Ellis RE and Horvitz HR (1992) Caenorhabditis elegans gene ced-9 protects cells from programmed cell death. Nature 356: $494-499$

Hengartner MO and Horvitz HR (1994) C e elegans cell survival gene ced-9 encodes a functional homolog of the mammalian proto-oncogene bcl-2. Cell 76: 665-676

Hu S, Peterson PK and Chao CC (1997) Cytokine-mediated neuronal apoptosis. Neurochem. Int. 30: 427-431

Huwiler A and Pfeilschifter J (1994) Interleukin-1 stimulates de novo synthesis of mitogen-activated protein kinase in glomerular mesangial cells. FEBS lett. 350: $135-138$ 
Kamens J, Paskind M, Hugunin M, Talanian RV, Allen H, Banach D, Bump N, Hackett M, Johnson CG, Li P, Mankovitch JA, Terranova M and Ghayur T (1995) Identification and characterization of $\mathrm{ICH}-2$, a novel member of the interleukin1 b-converting enzyme family of cysteine proteases. J. Biol. Chem. 270: 1525015256

Kim TW, Pettingell WH, Jung YK, Kovacs DM and Tanzi RE (1997) Alternative cleavage of Alzheimer-associated presenilins during apoptosis by a caspase-3 family protease. Science $277: 373-376$

Kostic V, Jackson-Lewis V, de Bilbao F, Dubois-Dauphin M and Prezdborski S (1997) $\mathrm{Bcl}-2$ : prolonging life in a transgenic mouse model of familial amyotrophic lateral sclerosis. Science 277: 559-562

Kuida K, Lippke JA, Ku G, Harding MW, Livingston DJ, Su MSS and Flavell RA (1995) Altered cytokine export and apoptosis in mice deficient in interleukin-1b converting enzyme. Science 267: 2000-2002

Kuida K, Zheng TS, Na S, Kuan C, Yang D, Karasuyama H, Rakic P and Flavell RA (1997) Decreased apoptosis in the brain and premature lethality in CPP32deficient mice. Nature 384: 368-372

Kumar S, Konoshita M, Noda M, Copeland NG and Jenkins NA (1994) Induction of apoptosis by the mouse Nedd2 gene which encodes a protein similar to the product of caenorhabditis elegans ced-3 and the mammalian IL-1b-converting enzyme. Genes Dev. 8: 1613-1626

Lee SC, Liu W, Dickson DW, Brosnan CF and Berman JW (1993) Cytokine production by human fetal microglial cells and astrocytes. Differential induction by lipopolysaccharide and IL-1 beta. J. Immunol. 150: 2659-2667

Levy-Lehad E, Wasco W, Poorkaj P, Romano DM, Oshima J, Pettingell WH, Yu CE, Jondro PD, Schmidt SD, Wang K, Crowley AC, Fu YH, Guenette SY, Galas D, Nemens E, Wijsam EM, Bird TD, Schellenberg GD and Tanzi RE (1995) Candidate gene for the chromosome 1 familial Alzheimer's disease locus. Science 269: 973-977

Lewis DB and Wilson CB (1990) Gamma-interferon: an immunoregulatory lymphokine with immunotherapeutic potential. Pediatr. Infect. Dis. J. 9: 642-651

Li P, Allen H, Banerjee S, Franklin S, Herzog L, Johnston C, McDowell J, Paskind M, Rodman L, Salfeld J, Towne E, Tracey D, Wardwell S, WEi FY, Wong W, Kamen R and Seshadri T (1995) Mice deficient in IL-1-bconverting enzyme are deficient in production of mature IL-1b and resistant to endotoxic shock. Cell 80: 401-411

Li W, Fishman MC and Yuan J (1996) Prevention of apoptosis in CNTF-dependent neurons by a mutant ICE and by viral protein CrmA but not by proto-oncogene product Bcl-2. Cell Death Differ. 3: 105-112

Li Y, Chopp M, Jiang N and Zaloga C (1995a) In situ detection of DNA fragmentation after focal ischemia in mice. Molecular Brain Research 28: 164-168

Li YMC, Jiang N, Yao F and Zaloga C (1995b) Temporal profile of in situ DNA fragmentation after transient middle cerebral artery occlusion in the rat. J. Cereb. Blood Flow and Metab. 15: 389-397

Lippke JA, Gu Y, Sarnecki C, Caron PR and Su MS (1996) Identification and characterization of CPP32/Mch2 homolog 1, a novel cysteine protease similar to CPP32. J. Biol. Chem. 271: 1825-1828

Loddick SA, MacKenzie A and Rothwell NJ (1996) An ICE inhibitor, z-VAD-DCB attenuates ischaemic brain damage in the rat. Neurorep. 7: 1465-1468

Loestsher H, Deuschle U, Brockhaus M, ReinhartD, NelboeckP, Mous J, Grunberg J, Haas C and Jacobsen H (1997) Presenilins are processed by caspase-type proteases. J. Biol. Chem. 272: 20655-20659

MacManus JP, Hill IE, Huang ZG, Rasquinha I, Zue D and Bucham AM (1994) DNA damage consistent with apoptosis in transient focal ischaemic neocortex. Neurorep. 5: 493-496

Martinou JC, Dubois-Dauphin M, Staple JK, Rodriquez I, Frankowski H, Missotten M, Albertini P, Talabot D, Catsicas S, Pietra C and Huarte J (1994) Overexpression of $\mathrm{BCL}-2$ in transgenic mice protects neurons from naturally occurring cell death and experimental ischemia. Neuron 13: 1017-1030

Mattson MP, Guo Q, Furukawa K and Pedersen WA (1998) Presenilins, the endoplasmic reticulum, and neuronal apoptosis in Alzheimer's disease. $\mathrm{J}$. Neurochem. 70: 1-14

Miura M, Zhu H, Rotello R, Hartweig EA and Yuan J (1993) Induction of apoptosis in fibroblasts by IL-1b-converting enzyme, a mammalian homolog of the $C$. elegans cell death gene. Cell 75: 653-660

Miyashita T, Okamura-Oho Y, Mito Y, Nagafuchi S and Yamada M (1997) Dentaorubral pallidoluysian atrophy (DRPLA) protein is cleaved by caspase-3 during apoptosis. J. Biol. Chem. 272: 29238-29242
Munday NA, VillancourtJP, Ali A, Casano FJ, MillerDK, Molineaux SM, Yamin TT, Yu VL and Nicholson DW (1995) Molecular clonning and pro-apoptotic activity of ICErelll and ICErellII, members of the ICE/CED-3 family of cysteine proteases. J. Biol. Chem. 270: 15870-15876

Munzio M, Chinnaiyan AM, Kischkel FC, O'Rourke K, Schevchenko A, Ni J, Scaffidi C, Bretz JD, Zhang M, Gentz R, Mann M, Krammer PH, Peter ME and Dixit VM (1996) FLICE, a novel FADD-homologous ICE/CED-3-like protease, is recruited to the CD95 (Fas/APO-1) death inducing signal complex. Cell 85: 817-827

Nicholson DW, Ali A, Thornberry NA, Vaillancourt JP, Ding CK, Gallant M, Gareau Y, Griffin PR, Labelle M, Lazebnik YA et al (1995) Identification and inhibition of the ICE/CED-3 protease necessary for mammalian apoptosis [see comments]. Nature 376: $37-43$

Osborn L, Kunkel S and Nabel GJ (1989) Tumor necrosis factor a and interleukin 1 stimulate the human immunodeficiency virus enhancer by activation of the nuclear factor kB. Proc. Natl. Acad. Sci. USA 86: 2336-2340

Portera-Cailliau C, Hedreen JC, Price DL and Koliatsos VE (1995) Evidence for apoptotic cell death in Huntington's disease and excitotoxic animal models. J. Neurosci. 15: 3775-3787

Ramage P, Cheneval D, Chvei M, Graff P, Hemmig R, Heng R, KocherHP, Mackenzie A, Memmert K, Revesz L (1995) Expression, refolding, and autocatalytic proteolytic processing of the interleukin- 1 beta converting enzyme precursor. J. Biol. Chem. 270: 9378-9383

Relton JK and Rothwell NJ (1992) Interleukin-1 receptor antagonist inhibits ischaemic and excitotoxic neuronal damage in rats. Brain Research Bulletin 29: $243-246$

Roagev El, Sherrington R, Rogaeva EA, Levesque G, Ikeda M, Liang Y, Chi H, Lin C, Holman K, Tsuda T, Mar L, Sorbl S, Nacmias B, Placentini S, Amaducci L, Chumakov I, Cohen D, Lannfelt L, Fraser PE, Rommens JM and St GeorgeHyslop PH (1995) Familial Alzheimer's diesease in kindreds with missense mutations in a gene on chromosome 1 related to the Alzheimer's disease type 3 gene. Nature 376: $775-778$

Rosen DR, Siddique T, Patterson D, Figlewicz DA, Sapp P, Hentati A, Donaldson D, Goto J, O'Regan JP, Deng HX et al (1993) Mutations in Cu/Zn superoxide dismutase gene are associated with familial amyotrophic lateral sclerosis. Nature 362: 59-62

Rothstein JD, Bristol LA, Hosler B, Brown RH and Kuncl RW (1994) Chronic inhibition of superoxide dismutase produces apoptosic death of spinal neurons. Proc. Natl. Acad. Sci. USA 91: 4155-4159

Sherrington R, Rogaev El, Liang Y, Rogaeva EA, Levesque G, Ikeda M, Chi H, Lin C, Li G, Holman K, Tsuda T, Mar L, Foncin JF, Bruni AC, Montesi MP, Sorbi S, Rainero I, Pinessi L, Nee L, Chumakov I, Pollen D, Brookes A, Sanseau P, Polinsky RJ, Wasco W, Da Silva HAR, Haines JL, Pericak-Vance MA, Tanzi RE, Roses AD, Fraser PE, Rommens JM and St George-Hyslop PH (1995) Cloning of a gene bearing missense mutations in early-onset familial Alzheimer's mutation. Nature 375: 754759

Namura S, Zhu J, Fink K, Endres M, Srinivasan A, Tomaselli KJ, Yuan J and Moskowitz (1998) Activation and cleavage of caspase-3 in apoptosis induced by experimental cerebral ischemia. J. Neurosci. in press

Schielke GP, Yang GY, Shivers BD and Betz AL (1998) Reduced ischemic brain injury in interleukin-1 beta converting enzyme-deficient mice. J. Cereb. Blood Flow Metab. 18: 180-185

Tewari M, Quan LT, O'Rourke K, Desnoyers S, Zeng Z, Beidler DR, Poirier GG, Salvesen GS and Dixit VM (1995) Yama/CPP32 beta, a mammalian homolog of CED-3, is a CrmA-inhibitable protease that cleaves the death substrate poly(ADP-ribose) polymerase. Cell 81: 801-809

Thomas LB, Gates DJ, Richfield EK, O'Brien TF, Schweitzer JB and Steindler DA (1995) DNA end labeling (TUNEL) in Huntington's disease and other neuropathological conditions. Exp Neurol 133: 265-272

Thornberry NA, Bull HG, Calaycay JR, Chapman KT, Howard AD, Kostura MJ, Miller DK, Molineaux SM, Weidner JR, Aunins J et al (1992) A novel heterodimeric cysteine protease is required for interleukin- $1 \mathrm{~b}$ processing in monocytes. Nature 356: $768-774$

Troy CM, Stefanis L, Prochiantz A, Greene LA and Shelanski M (1996) The contrasting role of ICE family proteases and interleukin-1beta in apoptosis induced by trophic factor withdrawal and by copper/zinc superoxide dismutase down regulation. Proc. Natl. Acad. Sci. USA 93: 5635-5640 
Verheij M, Bose R, Lin XH, Yao B, Jarvis WD, Grant S, Birrer MJ, Szabo E, Zon LI Kyriakis JM, Haimovitz-Friedman A, Fuks Z and Kolesnick RN (1996) Requirement for ceramide-initiated SAPK/JNK signalling in stress-induced apoptosis. Nature 380: 75-79

Vito P, Wolozin B, Ganjei JK, Iwasaki K, Lacana E and D'Adamio L (1996) Requirement of the familial Alzheimer's disease gene PS2 for apoptosis. J. Biol. Chem. 271: 31025-31028

Wang S, Miura M, Jung Y-K, Zhu H, Li E and Yuan J(1998) Murine caspase-11, an ICE interacting protease, is essential for the activation of ICE. Cell 92: 501-509

Wang S, Miura M, Jung YK, Zhu H, Galiardini V, Shi L, Greenberg AH and Yuan J (1996) Identification and characterization of Ich-3, a member of the interleukin1 beta converting enzyme (ICE)/Ced-3 family and an upstream regulator of ICE. J. Biol. Chem. 271: 20580-20587

Wang X, Pai JT, Wiedenfeld EA, Medina JC, Slaughter CA, Goldstein JL and Brown MS (1995) Purification of an interleukin-1 beta converting enzyme-related cysteine protease that cleaves sterol regulatory element-binding proteins between the leucine zipper and transmembrane domains. J. Biol. Chem. 270: $18044-18050$

Wellington CL, Brinkman RR, O'Kusky JR and Hayden MR (1997) Toward understanding the molecular pathology of Huntington's disease. Brain Pathology 7: 979-1002
Wolozin B, Iwasaki K, Vito P, Ganjei JW, Lacana E, Sunderland T, Zhao B, Kusiac JW Wasco W and D'Adamio L (1996) Participation of presenilin 2 in apoptosis: enhanced basal activity conferred by an Alzheimer mutation. Science 274 $1710-1713$

Wyllie AH, Kerr JFR and Currie AR (1980) Cell Death: The significance of Apoptosis. Int. Rev. of Cytol. 68: 251-306

Yakovlev AG, Knoblach SM, Fan L, Fox GB, Goodnight R and Faden Al (1997) Activation of CPP-32-like caspases contributes to neuronal apoptosis and neurological dysfunction after traumatic brain injury. J. Neurosci. 17: 74157424

Yuan J and Horvitz HR (1990) The caenorhabditis elegans genes ced-3 and ced-4 act cell autonomously to cause programmed cel death. Dev. Biol. 138: 33-41

Yuan Y, Shaham S, Ledoux S, Ellis HM and Horvitz HR (1993) The C. elegans cell death gene ced-3 encodes a protein similar to mammalian interleukin-1 $\beta$ converting enzyme. Cell 75: 641-652

Zou H, Henzel WJ, Liu X, Lutschg A and Wang X (1997) Apaf-1, a human protein homologous to $\mathrm{C}$. elegans ced-4, participates in cytochrome c-dependant activation of caspase-3. Cell 90: 405-413 